\title{
Learning in Serbia and Modern Information and Communication Technology
}

\author{
Milena Bogdanović* \\ University of Niš, Teacher Training Faculty, Partizanska 14, Vranje, Serbia \\ *Corresponding author: mb2001969@beotel.net
}

Received January 17, 2014; Revised February 25, 2014; Accepted March 18, 2014

\begin{abstract}
Modern educational technology with multimedia systems creates the preconditions for engaging all the senses in the process of acquiring new knowledge, develops students' creativity and provides greater activity of students in teaching and learning. Therefore, as computer science and information technology major features of education at all levels of education, from preschool to university. Today's students require different ways of learning. Growing up with the possibility of learning in virtual environments will become more independent and more willing to self-education and lifelong learning. Thus, young people who are now in elementary and secondary schools and those who are part of the formal education yet to enter, your life to be spent in active contact with information and communication technology in education and the need to be prepared for it. Information and communication technology (ICT) provides a good foundation for the creative and effective use of knowledge. Today at elementary schools educate a generation that will work in mid-21st century. Education in Serbia faces the challenges of reform and rapid adjustment to the demands of the developed environment, primarily the European Union standards, and intensive changes in science, technology, economics, and social relations as a whole. The question is what IT skills should be learned and how. What are the functional tasks of the educational process can be developed through teaching computer science? Are the students preparing for the process of lifelong learning and training? The role of contemporary modern teachers, among other things, to direct students to the creative use of information technology. The authors' intention is to highlight the problems that exist in Serbia in the application of modern ICT in teaching and education, but also some features of the implementation of ICT available to the Serbian students.
\end{abstract}

Keywords: information and communication technology, electronic sources of information, internet, education students, modern teaching, new forms of learning

Cite This Article: Milena Bogdanović, "Learning in Serbia and Modern Information and Communication Technology.” Journal of Computer Sciences and Applications, vol. 2, no. 1 (2014): 9-13. doi: 10.12691/jcsa-2-13.

\section{Introduction}

The beginning of the new millennium is a very dynamic period in the development of computer science and technology. The digital world makes support their daily life. The rapid development of computer discipline has substantial effects on education, both on educational content, and the educational methods. Thus, for example, networking and Web become a critical foundation of computer science, at the same time and one of the basic pedagogical resources, conditioning and changes in the educational process, not only in computer science but also in other areas.

The progress made in multimedia technology at the level of personal computers, as well as in networking technology and especially internet and web, created new opportunities to transform the teaching process and educational systems of significant scale, primarily in the developed world and in our country. The teacher's role in this process change. In planning the teaching process should be planned in such a situation in which the students will get to own the knowledge. Should be given to problem solving, and create problem situations students face the facts. The task of teachers is to determine the most reliable and efficient methods, forms of labor, facilities, teaching resources and sources of knowledge. Learning from different sources of knowledge is particularly important for active learning, which is one of the important features of modern education [5].

We are in a time that many call the era of modern information technology. It is quite real need for protocols and information form to digital form. There are many advantages - the systematic storage of information to an unlimited number of copies and nepropadanja in the physical sense. In practical terms, availability and reduces trpškove intangible form, and we task to take advantage of new technology by raising the level of education in general.

Modern educational technology with multimedia systems, creates the preconditions for engaging all the senses in the process of acquiring new knowledge, develop students' creativity and provide more active students in teaching and learning. Because the computer science and information technology relevant content of 
education at all levels of education, from preschool to university [1].

Modern education requires a new model of learning active learning, based on real-world information resources. Teachers today have to know how to use modern techniques and methods in education. Although its activities should change teaching contents and methods of procedure all levels of education, it is important to do these come informacji universities, and to the fakultetitima to educate students - future teachers, teachers in preschools. Basic education is one of the factors responsible for the development of society, so it is very important to its adaptability to change that now brings the information age. In order to successfully achieve these changes, it is not enough to change and modernize the teaching content, but it is equally important to make changes nestavnih methods and define new educational content and standards in teaching computer science. Find the most suitable solution for the education of young generations tomorrow to take on complex assignments in the modern information society, it is very responsible and delicate task. It was therefore necessary to allow the best preparation for entry into the modern business environment [6].

Every society strives for efficient, cost-effective and more democratic education, therefore the issue of the use of new information technologies in education is reduced to the problem of creating a theoretical ideal model of the use of these technologies at all levels of education. The most important task of the modern educational process is reflected in the increasing performance of existing and finding effective methods and forms of work.

The teaching process is necessary to actualize. The term includes the updating of teaching and systematic elements of contemporary society and the needs of modern man in the courses, the use of modern teaching aids. To actualised teaching, it is necessary to introduce innovations in education. Innovation is nothing new in the practice of education, a change in the content or methods of operation, and to improve the quality of teaching. It does not have to be something new, something better but that is adopted, implemented and improved.

\section{Internet and Knowledge Base}

The Internet is a "virtual company" computers and computer networks from around the world. With the help of computers, modems and phone lines, can be easily connected to all parts of the globe.

Internet, or popularly known as the "network of networks" has become by far the most popular means of communication. Internet services provide a simple, efficient and cost-effective solution for the exchange of information in various forms - content on the internet presents a multimedia way: using text, images and sound. It is available to everyone regardless of location, age and education - can be used by Internet experts, and computer illiterate. At each step, the Internet and information technologies are changing many aspects of life. We live, we buy, work, manage and communicate new ways that technology has enabled. Communication technology is the most pervasive technology of today. It is applied in every branch of industry, and in all areas of education and the basis for the successful operation of all social and state structures. Information and communication technology (ICT) provides a good foundation for creative and effective use of knowledge.

Computer literacy is a necessary part of today's business literacy. With classical knowledge needed to master the elements of information literacy, and enable it for use, development and understanding of information technology and its diverse applications in the economy and society, in other words - are trained to use computers and computer software. A lessons learned to know the procedure used in collecting and processing information for making correct and effective decisions about activities that should be followed - that is information literacy.

Information literacy skills include [7]:

1. Identifying information needs,

2. Finding information,

3. Analysis and evaluation of information,

4. The use of information,

5. Disclosure.

Today, the children are flooded with a variety of multimedia effects. Children who have a home computer with internet connection, know how to find pages of Pokemon or Harry Potter, but very few are on the Internet looking for some content that would help them to write a work of biology. There are few students who are looking for online educational games from which something can be learned, most would rather play a "destructive game". The task of teachers in schools to show children what a computer is actually used. Then the children, discovering new possibilities of the computer often leave their past activities on the computer [2].

Today, every computer literate teachers want a multimedia classroom libraries with educational software that could refresh their teaching that is now in many cases done with chalk and blackboard. It is necessary to encourage domestic production of educational software in Serbia, and provide a quality translation of foreign software (especially in science). This will ensure that information technology becomes a means of teaching in each subject.

Numerous electronic knowledge base offers nearly unlimited amounts of information about all the scientific achievements in all fields of science. Only need curiosity and a willingness to explore such content, and teaching shall, at all levels of education to become better and more effective.

Some of these sources of information in science are: Kobson, CiteseerX, Journal Citation Reports (ISI Web of Knowledge), Scopus, Web of Science (ISI Web of Knowledge), Academic search complete (EBSCOhost), ACM Digital Library (ACM portal), CAIRN, Cambridge Journals - HSS Collection (Cambridge Journals Online), Academic search complete (EBSCOhost), SpringerLink, Classics in the History of Psychology, Current Contents (OVID), ERIC - Educational Resource Information Center (OVID, EBSCOhost, ERIC), Open J-Gate, Project MUSE, Psyc ARTICLES (OVID), Questia, Science Direct.

\subsection{KoBSON}

Serbian Library Consortium for Coordinated Acquisition (KoBSON) is a new form of organizing a library of Serbia. The initiative to form the Consortium 
launched November 2001. The major research libraries in Serbia. KoBSON portal is available free of charge and authentication of all the academic domain IP in Serbia. It is necessary in the internet browser to set the appropriate proxy server university.

Since 2004. the customer is enabled and remote access ("the home" through a commercial provider) and under the same conditions as in the IP space of academic networks. Monitoring the usage of KoBSON indicates that about $30 \%$ of our users use information sources outside of normal working hours (night, weekends, holidays). In this mode, up to now we have registered 9500 researchers from Serbia, which is about a third of total number of researchers to the latest census, the Statistical Office. The only additional requirement consists in the fact that the customer signs a license which is obliged to comply with the terms of use. The right to own a license to all employees of the academic and scientific institutions founded by the Republic of Serbia and the Ministry of Science Fellows. Obtaining a license is free.

Past experience with KoBSON are very favorable. For less money than in the past in Serbia are now well over subscribed journals, including those of the highest quality. Success KoBSON a visible and internationally. In the first year of operation KoBSON is within a eIFL-occupied 32nd of 40 countries with respect to the number of downloaded articles and scribed resource, which is used as an indicator of success states. Today we take fourth location. In addition, according to UNESCO study on access to scientific literature, a Serbian leaders in the region. KoBSON provides customers more than 35,000 foreign scientific journals in electronic or paper form. The collection is offered to customers in Serbia, a large percentage of overlap with a list of Web of Science magazine, that the most significant world magazines. The source of the world in many libraries used for collections.

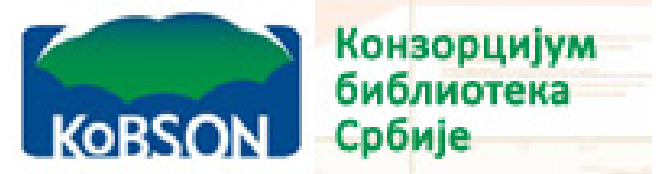

Figure 1. KoBSON

\section{New Ways of Learning}

At every turn, the Internet and information technologies are changing many aspects of life as well as in Serbia and elsewhere in the world. We live, we shop, we work, communicate and manage the new ways that technology has enabled. Information and communication technology is the most pervasive technology of our time. It has applications in every sector of the economy, and in all areas of education and the foundation for the successful operation of all social and state structures.

Learning is moving from traditional learning, learning through audio lessons, video lessons, e-learning, distance learning to the present form of mobile learning - $\mathrm{m}$ learning. Mobile learning is a kind of form of distance learning (d-Learning) and electronic learning - (eLearning).

The traditional way of teaching, which consist auditory lectures, and transfer of knowledge (training) a wider audience (students or disciples). Listeners are able or to remember information presented during lectures or to use some handy tools for annotating key elements in a lesson that could later in these notes to learn. Students remain independent and to "pass" books and other literature to extend traversed the course work. Teachers can also use certain assisted during lectures (e.g., blackboard and chalk).

The development of new technologies has enabled their use in the educational process. Keeping auditory instruction and reading from a book is still only part of the teaching process. Lectures are conducted through multimedia tools (video screen), the students use educational software to learn, use an online service for faster access to materials, while of tests performed by software testing.

Educational programs (or educational software) has long been used in education. These new programs (smart game) are of interest to users, especially younger age. Educational software can be viewed from two angles. On the one hand it is used educators (teachers, trainers, coaches, etc..) for efficient preparation and teaching, and on the other, it is a software designed to facilitate students master the curriculum, learning faster and more interesting. It is particularly important in the preschool and school training, because contains many fun elements.

Good educational software offers the possibility to learn through different levels. At least three levels may exist, beginner, intermediate and advanced. According to the test results recommended level of learning. Traditional concepts of software and learning should not be viewed in isolation, but rather as a combination of both approaches. Learning to use the software to support the traditional approach, not its total exclusion. Modern technology should be used to support the learning process. Its benefits must be used in accordance with the evolving needs and capacities, where today the space and time emerge as limiting factors.

Today, distance education can hardly be imagined without the significant use of ICT. However, a number of different software can create a negative initial attitudes toward distance education on both sides, so that potential teachers / instructors, and students in online classes. Lecturer / instructor should be familiar with all types of software (software) to be used in teaching. For successful implementation of specific teaching methods in distance education using appropriate technology needs to teacher / instructor for each software is available for use instructions. It is recommended that at least one and preferably several times, carry out training for the practical use of all types of software needed to perform elements of the on-line teaching as provided in the scenario of a learning process.

For the successful utilization of the pedagogical elements and methods of working with students in distance education it is important that the users in the forefront of educational content, and not having problems with technology. Appropriate technical equipment and computer literacy are essential prerequisites for a successful user participation in distance education. In addition to ensuring the necessary forms of technical support for users, we recommend evaluation of their technical equipment and knowledge of information technology prior to on-line education and to provide 
additional technical training or instruction for students who might have difficulty in mastering the use of educational technology.

Only oral presentation and presentation of educational content in the form of text usually causes information overload or problems related to attracting and keeping the attention of the instruction participants. Receiving information, only one communication channel makes it difficult to create associations and connect new information with previous knowledge and experiences. However, if information is presented as a combination of text, sound and image, it significantly increases the attraction of attention and deepens the experiences of the participants and creates a greater possibility of creating associations between different representations of certain information. However, it is necessary to take into account the principles of effective use of multimedia elements such as images and animations.

Using multimedia is extremely important in distance education as a lecturer is usually not physically present with the participants to draw their attention, motivate them to learn and explain the content that students are having difficulty understanding.

The application of certain methods in e-learning in a very large extent depends on the available technology. For example, if students can use a broadband Internet connection faster than 100 kbits per second or more (broadband), a lecturer / instructor can record lectures and has available the appropriate server memory capacity and speed of Internet access, the educational content can be stored in the form of video lectures [9].

On the other hand, if users access educational content via a slower dial-up connection or if the server is available to the teacher / instructor with limited memory capacity of a weak connection to the Internet, most of the educational content is probably the best prepared in the form of written text and static visual illustrations that do not take up much memory space.

Particularly useful to consider various alternative solutions for complex systems to manage the educational process / content (Learning Management System - LMS, learning content management system - LCMS). Such systems are usually integrated set of content on the web, testing, forums and communicate with users. However, if the teacher / instructor should only set exercises or tests and maintain a web forum on the web, it is useful to consider alternative solutions. For example, in forums and discussion groups can use the services of popular portals such as Yahoo, and for making on-line exercises and tests is available free software such as Hot Potatoes.

The term m-learning, as well as the first type of learning with mobile devices, first appeared in the 1970' $\mathrm{s}$ and 1980' s. In those years, Alan Key and his colleagues proposed that a mini computer that would replace the book. The name of the computer was Dynabook. The first serious aspect of this type of learning occurs in the course of the 1990' s. Then the company Palm offers a variety of discounts to educational institutions and companies that are using mobile learning in the Palm OS platform. It was not until the early 21st century European Commission starts to support projects related to m-learning and multinational project called MOBI learn (http://www.mobilearn.org/).
Mobile learning [10] is unthinkable without the use of mobile devices. Offer and purchase of mobile devices is a great availability depends on their prices. The advantage of mobile devices is that almost everyone can connect to the global world network called Internet.

Online learning can be defined as a form of education in which the learning content is presented to students via the Internet. When it comes to support for the program, which is used in education via the Internet, so commonly used Courseware tools, allowing storage of educational content on a Web server and their connection, communication between participants of the educational process, learning management, and test their knowledge through a variety of self-checking tests.

E-mail is the simplest form of asynchronous interaction and is usually used only as a supplement to other forms of communication. The advantages of using e-mail to: ease of use, communication is private, it allows plenty of time for reflection and response. Mailing lists are a service with similar forms of interaction. On-line forums and discussion lists enable the public, sending the questions, answers, share opinions, you can open your own discussion group on a particular topic. This method of communication allows large files do not take up space on our disks, allow training by correspondence, using file transfer for transfer of course material and the formation of bulletin boards to communicate with the teacher. Internet relay chat (IRC) is a synchronous communication based on text messaging over the Internet or Intranet in real time and to connect students with similar knowledge, students' gender, ability and objectivity of evaluation up the missed course work. FIT uses so-called combined transmission that partially covers the use of the Web, these Internet services as well as materials on hard disks for file transfer.

Lifelong Learning (permanently (permanent, continuous) education) is defined as the activity of learning throughout life, with the aim of improving knowledge, skills and abilities within a personal, civic, social and business prospects. It goes:

1. understanding of education as an ongoing aspect of daily life;

2. acquisition and modernization of all types of abilities, interests, knowledge and skills from preschool age to age after the end of its service life;

3. facilitate the development of knowledge and skills that will enable people to adapt "knowledge society" and active participation in all spheres of social and economic life and the impact on their own future;

recognizing all forms of learning (formal education (college, for example), non-formal education (training on the job) and informal learning, intergenerational learning (knowledge sharing in the family, for example).

\section{Conclusion}

Introducing such electronic information resources in science, the students will be able to use the same in both in the preparatory and in the implementation of classroom teaching, with the aim of modernizing the teaching process. Computer education is an essential prerequisite for inclusion in the contemporary trends. There are eight key competencies in education prescribed by the European 
Union. IT competencies are in fourth place, behind the mother tongue, foreign languages and mathematics. Research shows that Serbia is in terms of information literacy at the very bottom of the list of European countries. The biggest problems that have led to this situation in Serbia as insufficient equipment in primary schools with computers and appropriate educational software, and slow implementation of the opportunities provided by modern ICT. The financial situation also has a large stake in the current situation, raising the level of ICT use in teaching.

When it comes to new info-communication technology many experts believe that teachers need to acquire new knowledge, concepts and approaches, new attitudes are formed and have a different role in this environment. Therefore they are needed and different forms of professional development because of the nature of the educational process in the online sphere conditional nature of new info-communication technology and our ability to understand it - to be written for "electronic alphabet". Serbia has a long and successful history of development of Education and Science. Successful development of Serbia in equal measure depends on reaching scientific and technological modern standards and preserve the national character of education and upbringing. Openness to international developments in these areas assumes the existence of clear national goals and values.

\section{References}

[1] L. Twarog, M. Pereszlenyi-Pinter, "Telephone-assisted language study and Ohio University: Areport”, The Modern Language Journal, 72, 426-434, 1988.

[2] B. A. Green, K. J. Collier, and N. Evans, “Teaching tomorrow’s class today: English by telephone and computer from Hawaii to Tonga”, In L.E. Henrichsen (Ed.), Distance-learning programs (pp. 71-82). Alexandria, VA: Teachers of English to Speakers of Other Languages, Inc. 2001.

[3] B. J. David, Writing Space: Computers, Hypertext, and the Remediation of Print, Second Edition. Mahwah: Lawrence Erlbaum Associates, 2001.

[4] F. Librero, A. J. Ramos, A. I. Ranga, J. Trinona, and D. Lambert, "Uses of the cell phone for education in the Philippines and Mongolia”, Distance Education, 28 (2), 231-244.

[5] M. Bogdanović, "Educational Software, education and national education”, the Proceedings: The ability of national education in the globalization, p.p. 265-282, Teacher Training Faculty, Vranje.

[6] M. Bogdanović, "Internet - dve strane medalje", Inovacije u nastavi, časopis za savremenu nastavu, Vol. 24, br. 2, str. 131-133, Beograd,. (stručne informacije).

[7] D. Grahovac, B. Egić, "Standardizacija informatičke pismenosti učenika osnovnih škola", Pedagoška stvarnost, 57 (7-8), 740-749. (In Serbian) 2011.

[8] M. Bogdanović, "Multimedia and Education - features and options application”, International Conference on Information Technology and Development of Education ITRO 2011 Proceedings, pp. 308-311, University of Novi Sad, Technical faculty “Mihajlo Pupin”, Zrenjanin, Republic of Serbia, Zrenjanin, July 2011.

[9] B. Craig, New Directions of ICT-Use in Education, http://www.unesco.org/education/educprog/lwf/dl/edict.pdf.

[10] L. Stošić, M. Bogdanović, "M-leaning - a new form of learning and education", International Journal of Cognitive Research in Science, Engineering and Education (IJCRSEE), [S. l.], v. 1, n. 2, dec. $2013 . \quad$ Available at: <http://www.ijcrsee.com/index.php/ijcrsee/article/view/51/154>. Date accessed: 20 Dec. 2013. 